\author{
小玉 敏也 \\ 麻布大学
}

\begin{abstract}
Research of Nature Experience Learning in Hamanaka Town as Nature Conservation Education
\end{abstract}

\author{
Toshiya KODAMA \\ Azabu University \\ （受理日 2013 年 5 月 20 日）
}

\section{I 問題の所在}

2006 年改正の教育基本法では、新たな教育目 標として「生命を尊び、自然を大切にし、環境の 保全に寄与する」(第 2 条 4 号) との条文が規定さ れた。これを受けて学校教育法では、義務教育の 目標を達成するために「児童の体験的な学習活 動」や「自然体験活動」の充実に努めることが盛 り込まれ（2007年）、さらに教育振興基本計画で も「体験を取り入れた実践的な環境教育」の推進 が求められることとなった (2008年)。自然体験 学習は、これまで多様な主体（民間団体・企業等） によって実践されてきたが、こと学校教育におい ては上記の政策によって、ようやく国レベルでの 制度的基盤が整ってきたと言える。

本報告は、小玉 (2009a, 2011) の研究を要約 し今日的な視点から再考察を行うものである。こ れらの研究では、『浜中町自然体験学習 (環境教 育) 事業』(以下「自然体験学習事業」「事業」) を、 地域と学校が連携した自然体験学習の好個の事例 として研究の対象としてきた。本報告では、事例 の概要と特徴を概観し、その分析結果から得た知 見をもとに、自然保護教育の視点から浜中町の事 業の意義と課題を考察する。

\section{II 事例の概要}

\section{1 浜中町の概要}

北海道厚岸郡浜中町は、北海道東部の釧路支庁 管内東端に位置し、太平洋に面した人口約 8000 人の小規模な自治体である。約 $70 \mathrm{~km}$ に及ぶ海岸 線は、砂浜と岸壁からなり大小の島々が点在す る。内陸部に位置する霧多布湿原は、ラムサール 条約登録湿地に認定されているほか、その中央部 は霧多布湿原泥岩形成植物群落として国の天然記 念物に指定されている。町の基幹産業は農漁業 で、高い生乳生産額を誇る北部の酪農地域と、昆 布、サケ、サンマ等の豊富な資源に恵まれた南部 の漁業地域に分けられるが、経営環境の悪化や後 継者不足の問題を抱えながらも町民の約 $60 \%$ は 第1次産業に従事している。

近年では、豊かな自然を生かした霧多布湿原セ ンター(以下「センター」)を拠点とする観光業 (工 コッーリズム）も盛んになってきている。このよ うな地域特性を生かして、浜中町では1980年代 からまちぐるみの環境保全運動と先進的な環境教 育事業を展開してきた。

\section{2 自然体験学習事業の概要}

2005 年から実施された自然体験学習事業の目 的は、「浜中町の基幹産業が自然環境と深いかか 
わりを持っていることに目を向け、地域の自然や 人材、学校の特性を生かした環境に関する学習や 研究活動等の自然体験学習を通じて、児童生徒が 自然環境に興味を持ち、理解を深めることによっ て自然を大切に思う心を育成する」（浜中町教育 委員会，2006）ことにある。この目的の下に、町 内の全小中学校（小学校 11 校、中学校 5 校）は、 主に総合的な学習の時間（以下「総合的学習」） の中で授業化していった。一方、教育委員会は、 年3回以上の自然体験プログラムを実施すること、 その講師に地域人材(トラスト、センター、役場 職員、地域住民)を活用することを各校に求め、
活動全般に対する財政的支援を行ってきた。

このような教育委員会の施策の下で、各学校は センターの専任職員と連携しつつ本事業を推進し ており、各学校区のゆたかな地域資源（自然環境、 第 1 次産業、地域人材等）を教材化しながら共同 で授業プログラムを開発してきた。この事業は、 全小中学校での学校版 ISO の取組みとも連動しな がら実施されており、浜中町の重要な教育施策と して位置づけられてきた。下記の表 1 は、2010 年度の授業内容である。同町では、各校の実態に 合わせた多彩なプログラムが展開されていたこと がわかる。

表 1 浜中町における 2010 年度自然体験学習事業の内容

\begin{tabular}{|c|c|c|c|}
\hline 学校名 & テーマ & 学 習 内 容 & 学年 \\
\hline 霧多布小 & 浜中の自然を知り湿原を体験する & ·湿原探索 ·歩くスキー体験 & 4 \\
\hline 琵琶瀬小 & 「ふるさと琵琶瀬」学習 & $\begin{array}{l}\cdot \text { 湿原での生物観察 } \\
\cdot \text { 霧多布湿原でのフィールドワーク }\end{array}$ & $\begin{array}{ll}3, & 4 \\
5, & 6\end{array}$ \\
\hline 散布小 & 湿原の不思議の仕組みを学ぶ & $\begin{array}{l}\cdot \text { 手作り竿での川釣り体験 } \\
\cdot \text { 霧多布湿原探索 } ・ \text { 歩くスキー体験 }\end{array}$ & 3,4 \\
\hline 樈町小 & $\begin{array}{l}\text { 浜中町や榊町地域の自然にふれ } \\
\text { る } \\
\end{array}$ & $\begin{array}{l}\text { ·霧多布湿原の生物調査とセンター職員への質問 } \\
\text { • 野菜作り体験 } \quad \text { ·乗馬体験 } \\
\end{array}$ & 4 \\
\hline 貴人小 & 貴人地域の自然観察・調査 & ·湿地・山地の動植物分布と特徵の理解 & 全 \\
\hline 姉別小 & 湿原の仕組を探る & ・霧多布湿原探索による観察と調査 & $3,5,6$ \\
\hline 浜中小 & 僕達私達の浜中探検隊 & $\begin{array}{l}\cdot \text { 湿原探索（霧多布・琵琶瀬） } \\
\text { ·森林での体験学習 ・歩くスキー体験 }\end{array}$ & 3,4 \\
\hline 茶内小 & 湿原学習 & $\begin{array}{l}\cdot 2 つ の \text { 湿原探索（茶内・霧多布）と比較 } \\
\text { ·歩くスキー体験 }\end{array}$ & 4 \\
\hline $\begin{array}{l}\text { 茶内第 } 1 \\
\text { 小 }\end{array}$ & $\begin{array}{l}\text { 自然や郷土を愛する気持ちを } \\
\text { 養う }\end{array}$ & $\begin{array}{l}\text { ·学校林での野鳥学習、森づくり計画の実行 } \\
\text { ·森づくり体験 }\end{array}$ & 全 \\
\hline $\begin{array}{l}\text { 茶内第 } 3 \\
\text { 小 }\end{array}$ & 世界遺産「霧多布湿原」の自然 & ·霧多布湿原での生物調査、足跡観察 & $\begin{array}{l}2,3,4 \\
5,6\end{array}$ \\
\hline $\begin{array}{l}\text { 西円朱別 } \\
\text { 小 }\end{array}$ & 地域の自然にふれる & $\begin{array}{l}\text { ·学校周辺の草地での山菜採りと調理 } \\
\text { •森の学習 } \quad \text { 牧場での搾乳体験 } \\
\end{array}$ & 全 \\
\hline 霧多布中 & 地域を見つめて & $\begin{array}{l}\text { ·手作り竿による川釣り体験 ·湿原での野鳥観 } \\
\text { 察、足跡探し ·歩くスキー体験 }\end{array}$ & 1 \\
\hline 散布中 & 湿原を通して自然への関心を高める & ·川釣り体験・歩くスキー体験 & 1 \\
\hline 姉別南中 & 自然 & • ミズナラの森の生物調査、生態学習 & 1,3 \\
\hline 浜中中 & 浜中町の自然環境 & ·手作り竿による川釣り体験 & 3 \\
\hline 茶内中 & 浜中町の自然 & - 湿原の動植物調査 湿原の歴史 & 1 \\
\hline
\end{tabular}




\section{3 事例としての価値}

この地域を事例に選択した理由は、第 1 に浜中 町が霧多布湿原の保全に関する環境教育をまちづ くりの軸に位置づけ、とりわけ自然体験学習事業 を自治体行政の課題と密接に関連した教育政策と して展開してきたからである。そもそも浜中町 は、基幹産業の漁業と酪農業を持続可能な産業と して発展させていくことを基本方針としており、 その上に霧多布湿原の保全活動を含む観光業が位 置づく構図となっている（北海道浜中町 2000）。 このことを踏まえれば、先の事業目的には、一般 的な自然体験学習によって「自然大好きな子ど も」を育成するだけでなく、自然環境に配慮した 地場産業を維持発展させていくための人材育成と いう目的も潜在していたと解釈できる。また本事 業は、流出する若者を地域に繋ぎ止めるための施 策としての性格もあわせ持っていた。

第 2 の理由は、本事業が浜中町立霧多布高等学 校の教育活動とも深く関連している点である。本 校の教育内容は他の道立高校と大きな差はない が、町の教育政策に対応しやすい点と、町内出身 の生徒が大多数を占める点、卒業後も地元に残っ て家業（酪農、漁業等）を継ぐ生徒が多い点に独 自性がある。一般的には高校段階から小中学校の 学区域を離れる生徒が多いはずだが、小中学校時 代に自然体験学習を経験した生徒が、そのまま同 じ地域の高校に進学するケースは希少である。ま た本校の生徒は、総合的学習が施行された 2002 年に小学生時代を過ごし、自然体験学習事業が開 始された 2005 年に中学生時代を過ごした生徒で あることから、彼らは自然体験学習を実施する小 中一貫校に在籍してきたも同然であり、それ故に その意識の分析は自然体験学習研究の貴重な事例 となり得る。

第3に、本事業は中山間地域における自然体験 学習という一般性を持つ点に特徵がある。つま り、その地域固有の特性（地域資源のゆたかさ、 学校と地域の連带感等) と課題 (人口の流出、地 場産業の衰退、自治体の財政悪化等）を含む地域 で実践された典型的な事例として捉えることが可 能である。なぜなら、これまでの環境教育の事例
は、都市部周辺の郊外地域や第 1 次産業を基盤と した農山村・漁村地域で多く実践されてきた経緯 があり、当該地域のよさを学ぶ実践は目立つが、 地域の諸課題を対象化した実践はあまり見られな いからである(小玉, 2009b)。日本の中山間地域 一般が上記の特性と課題を共有するならば、浜中 町の事例分析はそこで自然体験学習を実践する意 義についても貴重な知見を提供することになるだ ろう。

今日の学校教育における自然体験学習とは「自 然体験活動を含んだ学習」と捉える見方が一般的 だが、以上のような特徵から、本事業は地域の実 態と課題に深く根ざした自然体験学習の事例とし て位置づけることができる。また、地域住民によ る霧多布湿原の保全活動を軸とした地域づくりの 一環として見ることもできるだろう。

\section{III. 調査の結果・考察}

\section{1 調査期間と方法}

この事例の調査は、大きく 2 期に分けて行った。 第 1 期は、2007年〜 2008年に「学校と地域教育 施設の協働過程における教員の力量形成」という 観点から調査を実施した。2007年は準備調査期 間で、関係者との面談から事業の概要を把握し た。2008年は本調查の実施期間で、同年 2 月に町 内全小中学校の事業担当教員に第 1 次質問紙調査 を、5月に前記教員とセンター職員に第 2 次質問 紙調査を実施した。第2 期は、2009年〜 2010年 に「児童生徒の自然体験学習に対する評価と地域 観」という観点から調査を実施した。8月に関係 者への聴き取り調査を実施し、同年 10 月〜 11月 にかけて小中学校と高等学校への質問紙調査を実 施した。2010年には、質問紙調査の結果を踏ま えて町内の中学生と霧多布高等学校の生徒、セン ター職員への面接調査を実施した。

以下、各調査から得られた結果を概括する。

\section{2 第 1 期の調査結果と考察}

(1)浜中町教育委員会は、各学校の自主性と主体 性を尊重しながら自然体験学習事業を主導してい た。これは、教育行政が各学校と地域教育施設を 連携する有効なシステムを構築できれば授業（事 
業）を円滑に進めることができる可能性を示唆す るものである。また各学校の教員は、各地域の実 態に合った多様な授業をセンター職員と共同で創 り出していく過程で、自然体験学習に関する教員 としての力量も身に付けていった。

(2)湿原センターの機能の1つに、情報提供機能 （学習資料の貸与、教師や子どもの質問への対応） があるが、センター職員の専門的知識・技能は、 教員の力量形成（教材研究、指導方法、コーディ ネート能力）に貢献していた。しかし、それは制 度的枠組の下で職員から教員に「伝達」されたの ではなく、いわば「非公式な学び」として教員が 「獲得」できた力量である。浜中町の教員は、セ ンター職員との対話による発見的、無意識的な学 びを反復しながら自然体験学習への理解を深め、 それを 3 年間継続したことによって、授業づくり に対する意欲が強化され学びの質も向上したもの と推測できる。

(3)自然体験学習に長期間関与した教員は、短期 的な教材論や授業方法論から、より長期的な視野 に立ったカリキュラム論に関心を移す傾向があっ た。これは地域教育施設が、学校との自然体験学 習カリキュラムの共同開発と、教員の研修内容の 検討及び研修会の実施をも担える可能性を示唆し ている。この「学校と地域教育施設の共同的カリ キュラム編成」構想は、国・県主宰の研修が教育 施策の「伝達」を基本任務とするのに対して、当 該地域の実態と各主体の問題意識に根ざしたカリ キュラムを編成し、そのプロセスそのものが教員 の主体的な力量の「獲得」となり得る点が明確に 異なる。

(4)学校と地域教育施設の連携システムが確立し、 相互の共同授業（事業）が活発化する段階では、 各主体と関係者による評価が極めて重要となるこ とが明らかになった。学校での評価は教員個々の ニーズや疑問を相互に共有し、教育委員会と地域 教育施設での評価は事業の計画・運営・内容に対 する各学校からの要望や意見を把握し、いずれも 次年度の事業活動の改善に繋げる作業が想定され る。これらの詳細なデータの収集は、各学校での 教員研修だけでなく、各自治体での研修内容を設
計する際にも発展的に活用できるものと考える。

\section{3 第 2 期の調査結果と考察}

(1)浜中町の児童生徒による「自然体験学習に対 する評価」は、地域の自然に対する関心、愛着、 保全意識が高く、自然体験学習そのものに対して 好意的な印象を持っていることが明らかになっ た。また、小学校時代に実施した自然体験学習が、 児童生徒の記憶に最も強く残る傾向にあった。そ の体験の内容は、体全体を動かしたり、対象に働 きかけたり、五感を刺激される等の諸体験が児童 期の原体験となって「自然優先的態度を取る価值 観」として定着したものと推測される(呉ら, 1998)。また本事業の場合は、専門的な知識を持 つセンター職員が、豊富な地域素材を教材化 (= プログラム化）し各学校の教師と共同授業を実施 したことが児童生徒の意識に大きな影響を与えた ことも明らかになり、前節で述べた「学校と地域 教育施設の共同的カリキュラム編成」という仮説 を支持する例証にもなった。

(2)「児童生徒の地域観」は、小中高校の自然体 験学習の経験が、地域自然への愛情を基礎としつ つ、それを基幹産業の維持発展に活用したいとい う意識に結びっくことが明らかになった。また、 観光資源としての霧多布湿原と豊かな水産資源を 活用すべきという意識や、その価值を他地域によ り広く発信することが地域の発展につながるとい う意識も育まれたと思われる。さらに、自然体験 学習に好感をもつ览童生徒は地域の諸課題に対す る関心や解決する意識が高かったことから、指導 者は自然体験学習を中学校・高等学校でのキャリ ア教育と有機的に関連づけたり、総合的な地域づ くり教育に発展させたりすることができるだろ う。もっとも、指導者が精緻なカリキュラムを編 成したとしても、児童生徒の認識構造の中に異な る要素・領域を結び付ける総合的・多面的な思考 力を醉成すること自体が困難であることも予想さ れ、これは授業論の課題としても検討する必要が ある。

(3)児童生徒が地域における自然と産業の関係性 を理解できた時、当該地域の将来像に関する一定 の認識を形成できることが明らかになった。換言 
すれば、自然体験学習が地域自然への愛情といっ た精神的な要素だけでなく、地域自然の社会的な 価值、地域経済との関連といった現実的な課題と も結びつけて指導できる可能性を示唆している。 とくに、浜中町のような中山間地域における自然 体験学習にはそれらの課題との結合が重要であ り、その要素をカリキュラムに盛り込むことに よって、地域における学校教育の重要性がさらに 増すものと考える。

\section{4 まとめ}

ここまでが、2期に渡る調查から導きだした結 果である。観点が異なる 2 種の調査を端的に要約 すると、豊かな教育資源 (自然・産業・人材等) をもつ地域において、学校と地域教育施設が有機 的に連携する自然体験学習は、児童生徒の自然 · 地域・産業に対する肯定的な感情や、各要素間の 関係性の認識、当該地域の将来像に関する認識を 培える可能性が高いということである。ただし、 それは双方の形式的な連携だけでは実現すること ができず、教員と施設職員が相互の専門性を生か しつつ、授業内容に関して継続的な協議ができる 環境を創り出していく、いわば「連携の質」を高 める努力がなされなければならない。そして、そ の協議を積み重ねていくプロセスそのものが教員 の力量形成に有意にはたらくという視点を持つべ きである。

\section{$\mathrm{N}$ 結論：自然保護教育の視点からの考察}

ここまで、学校での自然体験学習に言及してき たが、本事例を自然保護教育という大きな視点か ら考察してみたい。

小川（2009）は、自然保護教育についていくつ かの重要な指摘をしている。（1）環境問題の解決 を目指す目的教育／価值教育であるために学校教 育になじまない、（2）自然体験学習は自然保護か ら生まれたが、それは体験や学習が自己目的化・ イベント化・パターン化する傾向がある、（3）自 然保護教育の基軸は「自然認識」「感性」「社会認 識」「教育力」に整理できる、という 3 点である。 これらの指摘に即して、自然保護教育の視点から 本事業の意義と課題を考察してみたい。
（1）浜中町の自然体験学習事業は、1980年代 からの住民による環境保全運動と、それ以前の地 域保護者がもつ爱校心 (=「おらが学校」の意識) がなければ生まれることはなかっただろう。ただ し、その保全運動は、地域の自然破壊をくい止め るような対抗的運動の形態はとらず、行政・学 校・生産者組織が協働的関係を築きながら進める 賛成運動としての特質をもっていた（降旗2011）。 それは、湿原の保全を担う住民組織の名称が「霧 多布湿原にほれた会」(1983〜) ）「同ファンク ラブ」 $(1987 \sim) \rightarrow\lceil$ 同トラスト」 $(2000 〜)$ と 変遷してきたことからもよくわかる。この協働的 関係の段階的な発展が、浜中町の霧多布湿原に関 する自然保護教育のプロセスそのものであったと すれば、逆にそれが地域ぐるみの目的教育／価值 教育であったからこそ、浜中町の特色を表す教育 活動の一環として理解され、地域素材を活用した 個性豊かな共同授業を産み出すことができたと言 えよう。

(2)「体験・学習の自己目的化」という問題は、 III -2-(3)で指摘したカリキュラム論の観点から再 検討できる。都市 (周辺) 圈で自然体験学習を行 う場合は、既成のパッケージド・プログラムを活 用することが多く、確かに上記のような問題が起 こりやすくなるだろう。これに対して浜中町の事 業では、センター職員と教員間で年度毎にプログ ラムの微調整や修正が行われ、学校によってはカ リキュラムの再編成を通じてプログラムの位置づ けを修正する例もあったことから、自己目的化す る余地は相対的に低かったと思われる。また、各 学校の自然体験学習が、地域の自然・産業・人を 教材としていたことから、その学習目的には「地 域を知る・親しむ・愛する」という基調が暗黙の 裡にあり、なぜこのプログラムが実施されている のかという目的が、各校のカリキュラムに適切に 位置づけられている限り、児童生徒によく理解さ れていたものと思われる。

（3）4点の基軸を、学校での自然保護教育の問 題として引き取った時に、浜中町の事業からどの ような知見を導き出せるのだろう。各学校段階で 児童生徒の発達段階が異なるために正確な検討は 
できないが、本事業が事実上小中高と一貫して実 施されてきたことを踏まえて、4点の基軸をめぐ る考察のポイントだけを提示する。

「自然認識」: 主に生活科や理科等の教科を通じて 獲得できる認識だが、生の自然を教材とした自然 体験学習の場合、小学生が獲得した素朴な自然認 識は、中等教育における意図的・計画的な教科で の働きかけがない限り、生態系の動態・システム への基本的な理解には至らない。しかし、第 1 期 調查から推測すれば、児童期に体験的に獲得した 自然認識は中等教育において獲得する自然認識の 基盤を形成し補強する可能性を期待できる。 「感性」: 学校教育の中で「感性」それ自体を評価 することは困難を極める。それを、自然に対する 「関心」「好感」「愛着」という要因とほぼ同義と 捉えた場合、本事業を経験した児童期は高い定着 率を示すものの、学校段階が上がるにつれて低く なる傾向が明らかになった。ただし、その結果は 個別の意識調查を前提としているので、「感性」 を児童生徒の共同活動における関係性の視点から 評価していくことも重要だと思われる。

「社会意識」「教育力」: 霧多布高等学校のカリキュ ラム（総合「環境・郷土」、選択「郷土の自然」 地歴科「地域研究」）では、獲得した自然認識を、 町の産業や行政の課題と結びつけて教授しようと いう意図があった。また、本校の教員は地域での ボランティア活動への参加や尾瀬、谷津干潟への 視察旅行などを通して、社会的認識を形成する働 きかけを行ってきた。しかし、多くの困難な課題 を抱えた高校教育の中で「社会づくりへの意識と 使命感、行動力」を育成することは難しく、それ はむしろ高等教育が引き取る課題なのかもしれな い。それよりも、孤立的・個別的に生きがちな現 代の児童生徒が、自然体験学習を経験することで どのように内面が変容し、相互のコミュニケー ションを回復し、自己と距離のある「社会」とい う概念に関心を抱くようになるのかという視点か ら研究した方が現実的かつ生産的であるだろう。 また、教科や総合的学習の中で、地域の環境保全 運動の歴史や、日本／世界の環境問題解決の取組 みを教材化して授業を試みること（＝環境運動の
メ夕認知）の方が、児童生徒の社会認識を形成す るのに有効であるかもしれない。

以上、本報告は特定の地域を対象とした自然体 験学習の事例分析から、教員の力量形成、学校と 地域の連携、児童生徒の自然観・地域観といった 幅広い要因を考察し、自然保護教育との関係性に ついても言及した。今後は、学校での自然体験学 習の特質を、自然保護教育研究の史的課題の中で 理論的に検討する作業に取り組んでいきたい。

\section{引用文献}

降旗信一，2011，「自然体験学習における地域づ くり主体形成の拠点」, 『自然体験学習実践研 究』,「自然体験学習の指導者養成システムに 関する総合的研究」,自然体験学習実践研究会, 東京, 1 (3):70pp.

北海道浜中町， 2000 , 『浜中町第 4 期総合計画』 28-51.

浜中町教育委員会, 2006, 『平成 17 年度自然体験 学習 (環境教育) 実施報告書』.

小玉敏也，2009a，「自然体験学習に関する教員の

力量形成の課題 : 北海道厚岸郡浜中町に打ける 自然体験学習事業の事例分析」, 『自然体験学習 実践研究』, ネイチャーゲーム研究所, 東京,1(2), 5-19.

小玉敏也，2009b，「環境教育における『学校と 地域の連携』」降旗信一 - 高橋正弘（編著）『現 代環境教育入門』，筑波書房，東京,29-30. 小玉敏也, 2011,「学校での自然体験学習におけ るカリキュラム編成の課題 : 北海道厚岸郡浜中 町における自然体験学習事業の事例分析」、自 然体験学習実践研究』, 「自然体験学習の指導者 養成システムに関する総合的研究」, 自然体験 学習実践研究会, 1 (3):31-48.

点宣児 - 無藤隆, 1998, 「自然観と自然体験が環 境価值観に及ぼす影響」、『環境教育』, 7(2):11pp.

小川潔，2009，「自然保護教育の展開から派生す る環境教育の視点」, 『環境教育』,19(1):74pp. 